\title{
NEMÉNYI ÁGNES: ERDÉLYI FALVAK - GAZDASÁGI, SZOCIÁLIS STRUKTÚRÁK ÉS FOLYAMATOK
}

\author{
(Alsand Kiadó, Kolozsvár 1977. p. 138)
}

\section{PETHÖ LÁSZLÓ}

Egy évtizede folyó kutatásainak eredményeiböl közöl válogatást a kolozsvári Babes-Bolyai Egyetem szociológia professzora. A szerzỏ munkássága jól ismert a hazaai falukutatók körében, de eddig csak rövidebb tanulmányait olvashattuk vagy hallhattuk elöadásait szakmai összejöveteleken. A nemrégiben közreadott munka nyomán lényegesen differenciáltabb képet kapunk az Erdélyben folyó falukutatásról. A munka szerzője követi a romániai-erdélyi monografikus szociológia hagyományait és így egyáltalán nem véletlenül Venczel József emlékének szenteli könyvét. A követendő hagyományt mindamellett nemzetközi kitekintéssel párosítja, elemzései során felhasználja a faluszociológia legfrissebb eredményeit is.

A közölt dolgozat füzérböl árnyalt képet kapunk az Erdélyben élö magyarok társadalmi-gazdasági helyzetéröl. A hazai tömegkommunikáció által közvetített, javarészt rurálisként megjelenített magyarság-imázzsal szemben kiderül, hogy az Erdélyben élö magyarok $(58,25 \%)$ nagyobb arányban laknak városokban, mint a román állampolgárok átlaga (54,32\%). Sőt, mi több, vannak olyan megyék, ahol a magyarok túlnyomó többsége városlakó (Brassó 72,31\%, Hunyad 95,59\%). Ezzel szemben az is tény, hogy a két magyar többségü megye, Kovászna $(51,77 \%)$ és Hargita (42,85\%) urbanizációs mutatói lényeges szerényebbek az elöbbiekénél.

Legalább ennyire érzékletesek a továbbiakban közölt és elemzett demográfiai adatok. A lakosság korstruktúrája például egyre inkább kiegyenlitődést mutat. A századforduló idején még egyértelmüen a gyerekek, fiatalok és a középkorúak voltak a legnépesebb cohors-ok, velük szemben akkoriban az idősebbek száma lényegesen kisebb volt. Napjainkra viszont szembeötlóen kiegyenlítettebb a generációk képviselete, amely ugyanúgy következménye a szulletésszám csökkenésének, mint a fiatalok többirányú - belső és Magyarországra irányuló elvándorlásának, illetve aะ idősebbek léiszámát gyarapíú, javuló népešššsségügyi viszonyoknak.

A foglalkozásstruktúra elemzése alapján egy, a hazainál lényegesen tradicionálisabb kép elevenedik meg elöttünk. Az erdélyi magyarok körében a mezógazdasági foglalkozásúak $(35,3 \%)$ részesedése ma is meghaladja az iparban foglalkoztatottak $(21,2 \%)$ arányát. Erre vonatkozó kommentárjában joggal említi a szerző a Ceausescu-korszak gazdaságfejlesztési politikájának hibáit. A kőzkeletủen falurombolásként jellemzett politika a fejlesztési források e területtöl való megvonásával komoly modernizációs deficitet eredményezett a térség és az ott élö lakosság számára. A továbbiakban viszont arra is rávilágít a szerző, hogy az 1989 után bekövetkezett politikai változások hatására sem lett igazán perspektivikusabb a 
helyzet. A kollektív tulajdonlásra épített mezögazdálkodás egyik napról a másikra omlott ơssze, de a helyébe. lépő birtokstruktúra még a hazainál is lényegesen elaprózottabb. Az újra magántulajdonba került földek túlnyomó többsége 5 ha alatti, mindössze a birtokok $11 \%$-ának területe nagyobb ennél, $\mathbf{s}$ mindössze a tulajdonosok 0,3\%-ának(!) kezében van 10 hektárnál nagyobb földbirtok, melyböl nehezen alakulhat ki farmergazdálkodás.

Az összehasonlító telepưléskutatás iránt érdeklődő olvasók számára további fontos információkat tartalmaznak a Székelyföldön lefolytatott falukutatások, melyek közölt adataiból egyértelmüen kiviláglik, hogy a térségben éló emberek életének keretei meröben eltérnek a Magyarországon megszokottól. A székelyföldi falvak háztartásai këzül 63,3\%-ában nincs fürdőszoba, 67\%-ában van mosógép, $63,5 \%$-ában hütőgép és 61,9\%-ában található fekete-fehér, illetve 3,1\%-ukban szines televízió. Feltételezhetően nem kevésbé szokatlan az sem, hogy a lakóházak közilil lényegesen több épült fából és kőből, mint téglából. A legjobb szándékú fejlesztési elképzelésekkel szemben is komoly akadályt jelent a falvak humán eröforrásainak mérlege, hiszen az analfabéták $(1,2 \%)$ részesedését alig haladja meg az egyetemet $(1,6 \%)$ végzetteké. Így eröltetett aktualizálás nélkül is megállapítható, hogy a Romániában élö magyarság oktatásügyének fejlesztése valóban a legfontosabb feladatok egyike.

A figyelmesen böngésző olvasó az ízelítóül kiemeltek mellett további hasznos információkat talál még a magánvállalkozásokról, a társas vállalkozások helyzetének alakulásáról és a vidéki pedagógus társadalomról. Jó lenne, ha legalább minden magyar szakkönyvtárban hozzáférhetỏvé válna ez a munka. 